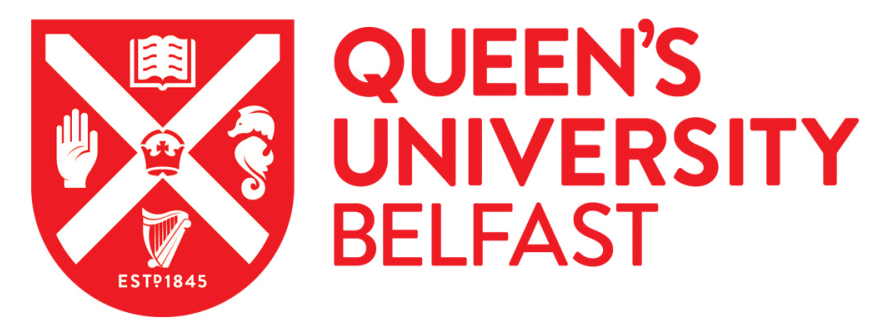

\title{
Trends In Child Protection Across The UK - A Comparative Analysis
}

Bunting, L., \& McCartan, C. (2017). Trends In Child Protection Across The UK - A Comparative Analysis. British Journal of Social Work. https://doi.org/10.1093/bjsw/bcx102

Published in:

British Journal of Social Work

Document Version:

Peer reviewed version

Queen's University Belfast - Research Portal:

Link to publication record in Queen's University Belfast Research Portal

Publisher rights

Copyright The Author 2017. Published by Oxford University Press on behalf of The British Association of Social Workers. All rights reserved. This work is made available online in accordance with the publisher's policies. Please refer to any applicable terms of use of the publisher.

\section{General rights}

Copyright for the publications made accessible via the Queen's University Belfast Research Portal is retained by the author(s) and / or other copyright owners and it is a condition of accessing these publications that users recognise and abide by the legal requirements associated with these rights.

Take down policy

The Research Portal is Queen's institutional repository that provides access to Queen's research output. Every effort has been made to ensure that content in the Research Portal does not infringe any person's rights, or applicable UK laws. If you discover content in the Research Portal that you believe breaches copyright or violates any law, please contact openaccess@qub.ac.uk. 


\section{TITLE - TRENDS IN CHILD PROTECTION ACROSS THE UK - A}

\section{COMPARATIVE ANALYSIS}

\section{Authors}

Bunting, L. ${ }^{\text {a * }}$

McCartan, C. ${ }^{b}$

McGhee, J. ${ }^{\mathrm{c}}$

Bywaters, P. ${ }^{d}$

Daniel, B. e

Featherstone, B. ${ }^{f}$

Slater, T. ${ }^{g}$

a* Corresponding author - Queen's University, School of Sociology, Social policy and Social Work, 6 College Park, Belfast, BT7 1NN, UK. Tel 02890971482, Email I.bunting@qub.ac.uk

b Queen's University, Belfast, UK

c School of Applied Social Science, University of Stirling, EH8 7LF d Coventry University, UK e University of Stirling, UK f University of Huddersfield g Cardiff University

Funding - This project has been generously by the Nuffield Foundation 


\section{TRENDS IN CHILD PROTECTION ACROSS THE UK - A COMPARATIVE ANALYSIS}

\section{ABSTRACT}

Although numerous international studies point to large variations in child welfare interventions, comparative analysis has tended to focus either solely on England or the UK as a whole, discounting differences across the four UK countries. This paper compares trends in national statistics relating to the operation of child protection systems across England, Scotland, Wales and Northern Ireland between 2004/5 and 2013/14. Despite a number of legislative, operational and definitional differences between nations, a number of trends are apparent. All systems show an increasing orientation towards child protection as evidenced by rising rates of child protection investigation and children subject to child protection planning. Increasingly, this relates to emotional abuse and involves younger children aged 0-4 years. However, the way cases are processed can differ with only one in ten referrals resulting in a child protection investigation in Northern Ireland compared to one in five in England. Potential reasons for these differences are discussed and questions raised as to why, more than quarter century after the introduction of the Children Act 1989, we still have no clear picture of the circumstances of families who come into contact with social services or the services provided to support them.

KEYWORDS: Child protection, Children and families, Comparative social work, Cross-national research

SUBJECT CATEGORIES: Child Abuse and Protection, Government and Social Policy

\section{INTRODUCTION}

Numerous international studies point to very large variations in child abuse reporting rates as well differences in patterns and rates of child welfare interventions between and within a range of countries (see for example Gilbert et al. 2012; Gilbert, 1997; Bunting and Wallace, 2007; Munro \& Manful, 2012; Tilbury and Thoburn, 2008). Most notably, comparative analyses of official statistics have been used by Gilbert (1997) to identify two different welfare state models, the child protection model (England, Canada and the US) and the family support model (Sweden, Denmark Finland and the Netherlands). More recent analyses (Gilbert et al., 2011) point to greater international convergence between these two models over time across a range of countries, as well as the emergence of a third child-focused orientation. While providing a valuable framework for interpreting variations between countries, UKbased comparative research, to date, has tended to focus either solely on England or the UK as a whole, discounting differences across the four UK countries of England, Northern Ireland (NI), Scotland and Wales.

Although qualitative comparison (Stafford et al., 2012) points to considerable commonality amongst constituent UK countries with regard to child protection legislation, structures and procedures, a cursory glance at recent national statistics shows considerable variation between nations; at the end of 2013/14 Scotland had the lowest rate of children subject to child protection plans (28 per 10,000) and Wales the highest (50 per 10,000), while England had the lowest rate of children looked after by 
the state (60 per 10,000) and Scotland the highest (156 per 10,000). Likewise, at a sub-national level, research in 14 English local authorities has also revealed very large inequalities in a child's chances of becoming subject to a child protection plan or of becoming looked after both between and within local authorities (Bywaters et al., 2014). A child in the most deprived decile of neighbourhoods in England had a 10 times greater chance of being placed on a CPP and a 12 times greater chance of being looked after than a child in the most affluent decile.

As part of a major grant awarded by the Nuffield Foundation, the Child Welfare Inequalities Project (CWIP) is now replicating and extending the work of Bywaters et al. (2014) across the UK. A key element of the CWIP involves examining variation in child protection figures collected across England, Scotland, Wales and (NI) to assess the extent of comparability and consider how a range of factors may contribute to variability. This is the first in a series of articles comparing trends in official data relating to the operation of the child protection and looked after systems across UK countries. The primary focus of this paper is on child protection processes and it presents data for each UK nation over the ten year period 2005-2014. To set these figures in context and provide a tentative framework for interpretation, key components of the legislative, policy and practice context are summarised.

\section{NATIONAL LEGISLATIVE, POLICY AND PRACTICE CONTEXT}

\section{Legislation and Structures Underpinning Child Protection across the UK}

Although all parts of the UK have undergone significant reform of child protection policy over the past decade, particularly in relation to the Children Act 2004 in England and Wales, this has tended to focus more on structural and procedural reform aimed at improving planning, intervention and integration. The Children Act 1989 and equivalent legislation in Scotland [Children Act (Scotland) 1995] and NI [Children Order (NI) 1995] remain the legislative foundation of each national child protection system. Across all nations this places a duty on local authorities to both support families in which children are deemed to be in 'need' as well as investigate cases in which children are considered to be at risk of 'significant harm'. The NI legislation contained some amendments in recognition that, uniquely, it operated an integrated health and social care system. However, the Scottish legislation contained more significant amendments which took account of separate legal and child protection structures unique to Scotland in the form of the Children Hearing System (CHS).

The CHS, an integral element of both child protection and youth justice systems in Scotland since 1971, was reformed by the Children's Hearings (Scotland) Act 2011 which now provides the legal basis for child protection measures in Scotland. The children's hearing is a non-adversarial tribunal involving a lay panel of volunteers which provides an informal setting for parents, children and panel members to make decisions based upon the needs of the child (McGhee \& Waterhouse, 2012). In England, Wales and NI, where there are child protection concerns necessitating some kind of statutory intervention, local authorities make an application to the Family Law Courts for a variety of legal orders. In Scotland local authorities can make also an application to the Scottish courts (Sherriff Courts) for child protection measures but they also have the option of applying for a Compulsory Supervision Order through the CHS. Importantly, significant harm as a criterion is only specific to child protection measures heard by the Sherriff Courts while CSOs encompass a broader range of concerns including the need for guidance, treatment or control as well as protection. 
As such, the CHS provides an alternate legal route for the protection of children in addition to the administrative systems of child protection. Additionally, children who are made subject to CSOs but remain at home with their families receiving support are defined as 'looked after' in Scotland.

\section{Guidance and Assessment}

All UK nations produce and update guidance (All Wales Child Protection Procedures Review Group, 2008; DHSSPS, 2015; DfE, 2015; Scottish Government, 2014b; Welsh Government, 2004) which operationalises the Children Act/Order legislation and outlines the roles and responsibilities for various agencies, in particular social services, in protecting and promoting the well-being of children. While England, Scotland and Wales have traditionally relied on a system of voluntary reporting which emphasises information sharing and inter-agency co-operation (Bunting et al., 2010), Wales has recently introduced mandatory reporting for local authority 'partners' through the Social Services and Well-being (Wales) Act 2014 and recent changes to the Female Genital Mutilation Act (2003) now also places a duty for professionals to report 'known' cases in England and Wales. In NI Section 5(1) of the Criminal Law Act (1967) provides for a criminal offence of failing to disclose an arrestable offence to the police, which, de facto, includes most offences against children. However, as this legislation was introduced to address concerns about terrorism and is not referenced in child protection guidance, its applicability to child welfare cases appears limited.

While child protection guidance in each nation covers the four broad maltreatment areas of physical abuse, sexual abuse, emotional abuse and neglect there are some definitional differences between countries as well as changes within countries over time (see Bywaters et al., 2016 for more detailed analysis). For example, in England, Wales and Scotland neglect is broadly defined as the persistent failure to meet a child's physical and/or psychological needs. However, the recent Social Services and Well-being (Wales) Act 2014 has excluded 'persistent' from the Welsh definition while recent guidance in $\mathrm{NI}$ has removed reference to 'persistent' and focused more on the failure to meet physical needs (DHSSPS, 2015). In England emotional abuse is defined as "the persistent emotional maltreatment of a child such as to cause

severe and persistent adverse effects on the child's emotional development" (DfE, 2015, p92). While devolved UK nations also include 'persistent' in their definitions of emotional abuse the range of behaviours covered varies between considerably with England having the most extensive current definition

(DfE, 2015). Importantly, this definition and one which has changed significantly from earlier guidance (HMSO, 1991) published following the introduction of the Children Act 1989.

All nations have adopted a common framework for assessing the needs of children and families. The Framework for the Assessment of Children in Need and their Families (FACNF) (Department of Health, 2000), intended for use as a specialist assessment tool, primarily by social workers, was introduced in England and Wales to provide a systematic and consistent way of collecting and analysing information about children who were thought to be 'in need'. By contrast the Common Assessment Framework, introduced in 2006, was designed to be used by practitioners in all agencies to identify additional needs at an earlier stage. Scotland and NI have also introduced assessment frameworks, Understanding the Needs of Children in NI (UNOCINI) [DHSSPS,2006a] and the Getting it Right for Every Child (GIRFEC) in Scotland (Scottish Government, 2008). Each of these frameworks use the same 
'assessment triangle' cover the three domains of the child's development, parenting capacity and family/environmental factors used in the FACNF and CAF. Although currently still in use in England and Wales, as both the FACNF and CAF were Labour initiatives, they have tended to be less visible under subsequent Governments.

\section{Directions in Family Policy}

Social policy in the UK has developed considerably in recent decades with the thirteen year reign of the Labour Government (1997-2010) being a particular time of radical family policy development and investment more generally. Over the course of three administrations Labour broadened the focus of intervention from child protection to safeguarding through the Every Child Matters (ECM) green paper (Her Majesty's Government, 2004) and associated Children Act 2004, and introduced a swathe of initiatives to better support parents such as the roll out of the national Sure Start programme, the development of Children's Centres and investment in a range of parenting support, education and childcare services. Services originally intended as targeted programmes came to take on a more universalist approach with Sure Start Local Programmes evolving into Sure Start Children's Centres (SSCCs) and the introduction of children's centres in every community (Frost et al., 2015). Labour also focused on developing more targeted and integrated services to meet the need of families experiencing multiple disadvantage and at high risk of 'social exclusion' through its "Think Family" initiative (Social Exclusion Taskforce, 2008). Reducing child poverty was also a key target for Labour as exemplified in the Child Poverty Act 2010 which required the UK and devolved governments to publish child poverty strategies and annual reports outlining their progress towards ending child poverty.

However, with the onset of the financial crisis in 2008 and election of the Conservative/Liberal Democrat Coalition government in 2010, the unprecedented investment in child and family services came to an end. The first spending review of the Coalition Government (HM Treasury, 2010) brought about significant reductions in central government funding for local authorities with the most deprived populations suffered disproportionately higher levels of cuts (Hastings et al., 2015). This was accompanied by some of the biggest ever reforms to UK welfare which resulted in unprecedented cuts to social security. Progressive universalism was eschewed under fiscal austerity and a more targeted approach to family support delivery was promoted (Frost et al., 2015). Policy development continued to be focused on prevention and early intervention (Allen, 2011), particularly in the first five years of a child's life, but increasingly took on a more authoritarian tone against a background of reductions in family support services (Featherstone et al., 2014). The 'Troubled Families' programme (HM Government, 2012), drew heavily on Labour's 'Think Family' agenda and became a major initiative targeting families experiencing multiple and complex problems in a more integrated way. Family Intervention Projects were positioned as forms of primary intervention targeted at the lives of the most 'chaotic families' who were costing the taxpayer in terms of service and resource allocation. The discourse of safeguarding gave way to a sharper focus on child protection and, despite the Munro (2011) call for 'early help' rather than 'early intervention', discussion of family support remained limited (Featherstone et al., 2014) and anti-poverty measures increasingly focused on individual and family deficits (Churchill, 2013).

The themes of early intervention, integrated children's services provision and development of whole family support approaches have also been common to policy development across Scotland, Wales and NI (Davidson et al., 2012), although some 
variation in approach has also been evident. While discussion of ECM largely disappeared under Coalition and Conservative Governments in England, equivalent children's strategies in the devolved administrations (DHSSPS, 2006b, Scottish Government; 2008; Welsh Government, 2011) remain central to family policy and service provision. Wales and Scotland have both embedded an early intervention approach within legislation through the Social Services and Well-being (Wales) Act 2014 and Child and Young Persons (Scotland) Act 2014 with the latter placing some elements of Scottish children's strategy "Getting in Right for Every Child" (2008) on a statutory footing. In NI the regional Children and Young People's Strategic Partnership (CYPSP), responsible for integrated planning and commissioning to improve outcome for children, published NI's first ever Children and Young People's Plan in 2011 and established family support hubs across $\mathrm{NI}$ to provide better access to, and coordination of, statutory and community support services.

Children's strategies in the devolved nations have also tended to reflect a more explicit focus on children's rights than their English counterpart with both Scotland and Wales incorporating the UNCRC into domestic legislation through the Child and Young Person (Scotland) Act 2014 and the Children and Young Persons (Wales) Measure 2010. Uniquely within the UK, the Children \& Families (Wales) Measure 2010 also provides a legal mandate for the provision of integrated family support services in Wales and requires Ministers, local and other authorities to develop anti-poverty strategies (McCormick, 2013). Welsh Child Poverty Strategies (Welsh Government, 2011 \& 2015) reflect the statutory framework set out in the 2010 Measure and explicitly recognise family support policy as integral to the eradication of poverty. Likewise Scotland and NI have specific child anti-poverty strategies (Scottish Government, 2011; DHSSPS, 2006b) which underpin family policy in these jurisdictions and reaffirm a commitment to support families and communities experiencing difficulties through a range of provision. Although the devolved administrations are constrained by the fact that the bulk of tax and welfare powers are reserved to Westminster, Scotland, in particular, has made significant in-roads in reducing the proportion of children living in poverty (Lodge et al., 2015). Rates in Wales and NI share the same downward trajectory but have tended to be more volatile over time remaining higher than in England or Scotland.

\section{DATA COMPARABILITY AND TEN YEAR TRENDS}

\section{Methodology}

The data presented in this paper is derived from national administrative data published annually in each of the four UK nations. Previous work examining the comparability of official child welfare statistics (Munro et al., 2011) has shown that, despite the breadth and detail of statistical data collections in each nation, there are limits to how far these statistics can be compared. Broadly speaking, data collected in England and Wales tend to be more closely aligned while there is greater divergence in the data items and classifications used in Scotland and, to a lesser degree, NI. Building on the work of Munro et al. (2011) and Jutte et al. (2015), the data presented in this paper are based on a range of statistics identified as identical or broadly comparable across some or all nations. An overview of different definitions and data categorisations impacting comparability can be found in the supplementary material accompanying this article together with references to the source material. Findings and analysis are structured to follow the 'filter-and-funnel' process which characterises UK child protection processes (Hood et al., 2016). Cases are tracked from the initial 'funnel' (referral) into 
the system and through the various 'filter' stages of assessment, initial case conference and child protection planning or registration (CPP/CPR). Rates of children per 10,000 at the census date are presented alongside annual activity statistics calculated both as the rate per 10,000 children and as a percentage of referrals during the year.

Where available, five year trend data for England, Wales and NI covering the years 2009/10-2013/14 have been taken from the most recent statistical publications (2013/14) and earlier trend data covering 2004/05-2008/9 have been taken from 2008/09 statistical publications. Where trend data were not available, statistics were sourced from individual annual publications covering the time period 2004/05 $20013 / 14$. Likewise, where available, rates per 10,000 children published in official reports have been used and, where unavailable, they have been calculated using the 2005-2014 mid-year population estimates for each of the nations (ONS, 2014). All data relating to Wales has been taken from the national data system available online, StatsWales (https://statscymru.cymru.gov.uk).

\section{Results}

\section{Referral Rates and Cases Assessed by Children's Social Care}

All the nations, except Scotland, collect data on the number of referrals to children's social services received and define this in the same way. Figure 1 shows the rate of referrals to children's social services have been increasing in England and NI over the past decade. In England numbers and rates stayed roughly the same between 2004/5 and 2008/9 and then rose albeit unevenly over the next five years. In Wales referrals have tended toward greater fluctuation but have been decreasing since 2010 . However, official statistical reports (Statistics Wales, 2015) have noted that a contributing factor to the fall in the number of referrals has been the exclusion of contacts which did not result in a subsequent referral, data which was incorrectly included by some local authorities in previous years. NI has a significantly higher referral rate than the other countries, a disparity which has been maintained and increased over the past decade.

\section{Fig 1}

Figure 1 - Rates of Referrals During Year per 10,000 children (20052014)

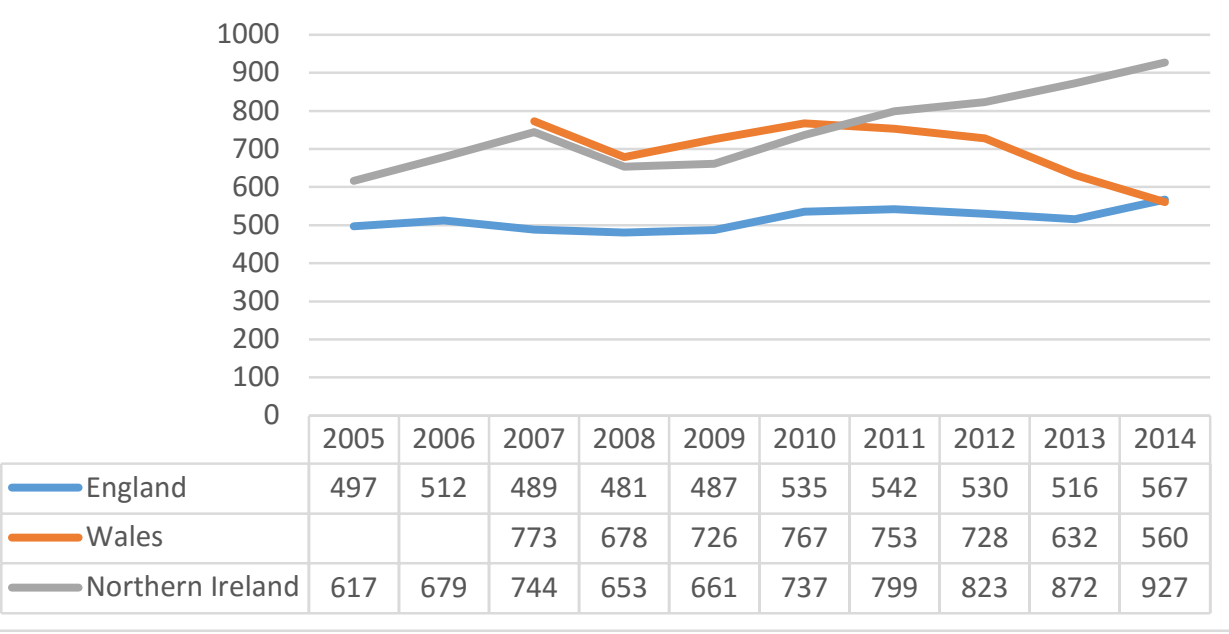


In terms of assessment, England and Wales provide data on the number of initial assessments completed during the year. Data indicate substantial changes over time in the proportion of referrals which have resulted in an initial assessment being completed, rising to roughly more than three quarters of all referrals in 2013-2014 (a calculation is not possible for 2014 in England as many local authorities moved to a process of continuous assessment during the year). The figures for England have risen more incrementally than in Wales which has seen a significant increase from $50 \%$ in 2010 to $79 \%$ in 2014.

While there is no equivalent assessment data for $\mathrm{NI}$, figures are collected on the proportion of children referred whose cases were allocated for further action following initial assessment of the referral, either through further assessment or service provision. These indicate that the proportion of cases actioned has fluctuated since 2009, reaching a high of $80 \%$ in 2011 but dropping recent years to $71 \%$ in 2014 .

\section{Fig 2}

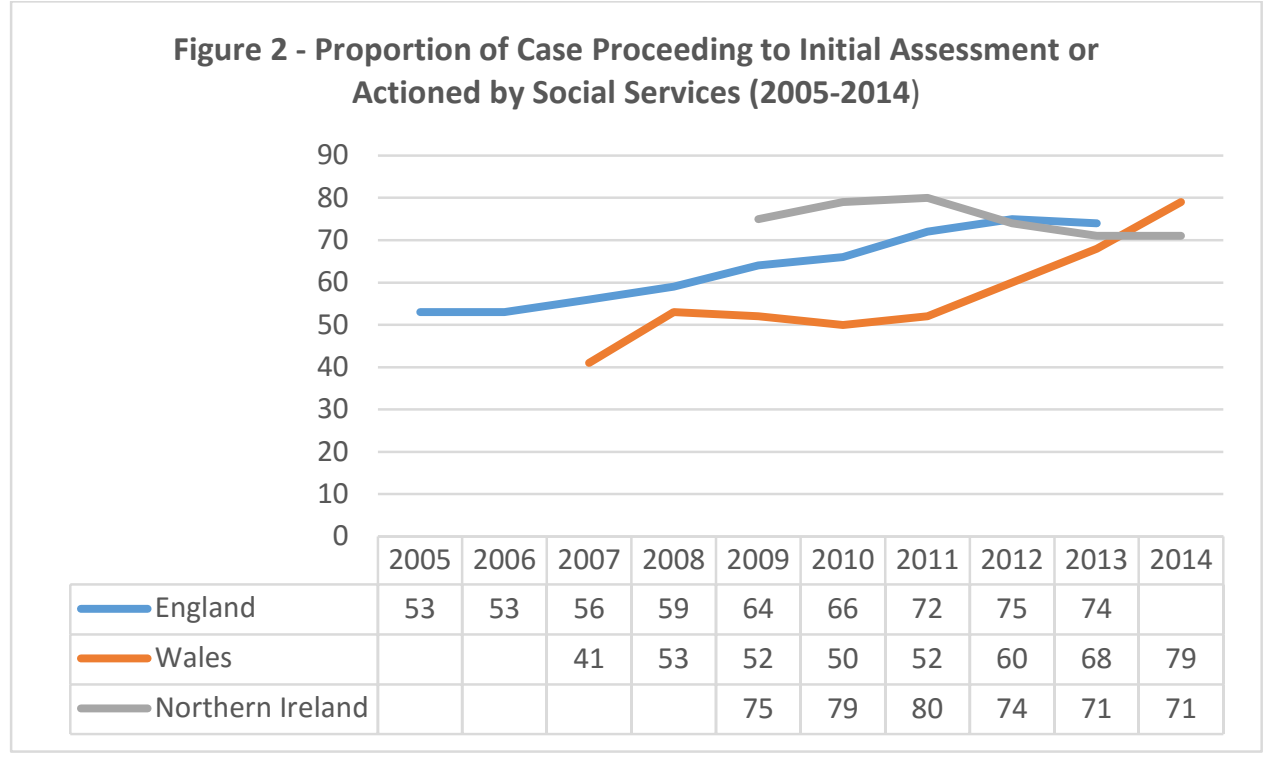

\section{Rates of Children Subject to Child Protection Plans/ Registration}

All UK nations collect statistics on the rate of children per 10,000 subject to child protection plans (CPPs) or child protection registration (CPR) at a given time point in the year. As we can see from Figure 3, Scotland has consistently maintained a significantly lower lever of children on the register than any other nation over the past ten years although, as with England and Wales, this has been increasing over time. $\mathrm{NI}$ has, historically tended to have higher rates than other nations although this has decreased in recent years and has recently been overtaken by Wales.

\section{Fig 3}




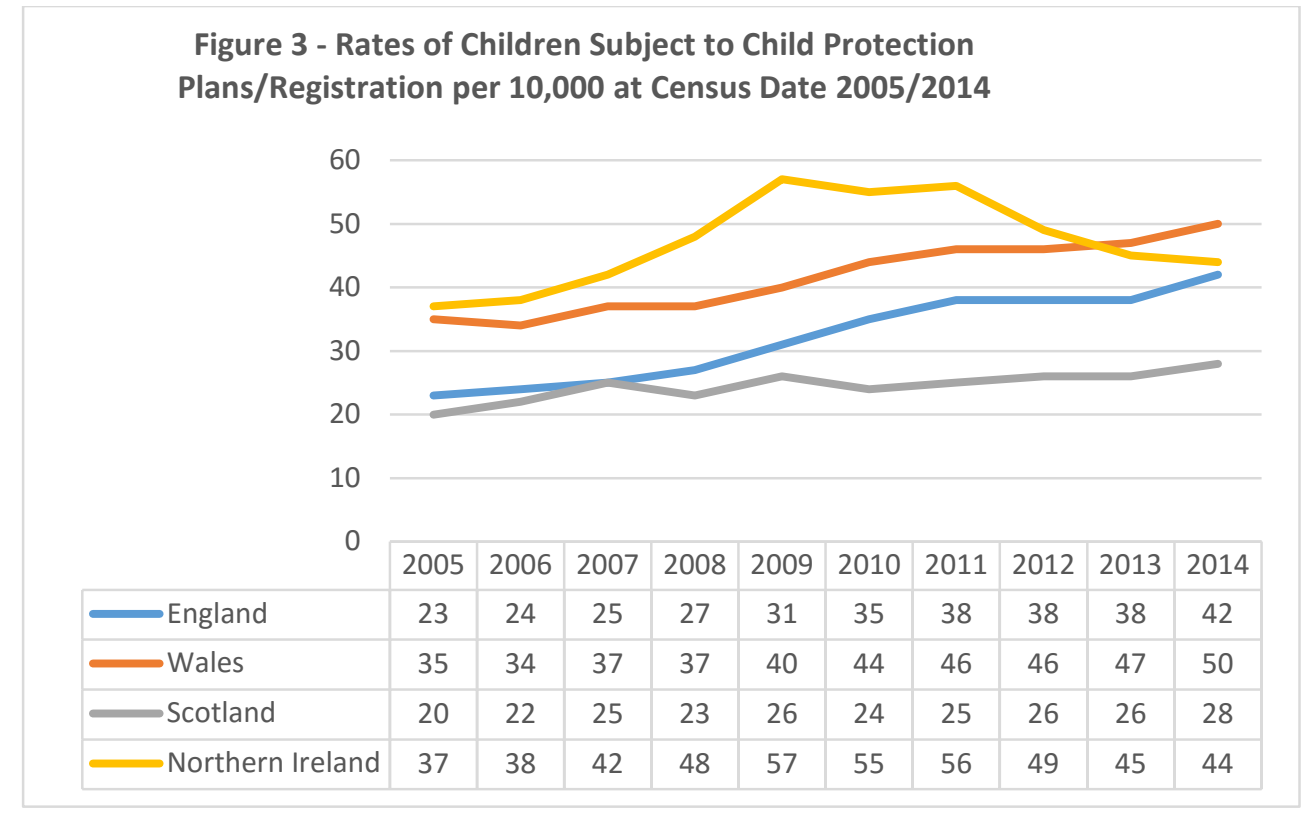

Child protection investigations, initial case conferences and registrations during the year

Only England and $\mathrm{NI}$ collect data on the numbers of child protection investigations/enquiries started during the year. As Table 1 highlights, the rate of investigations in England and $\mathrm{NI}$ has been steadily increasing over time although $\mathrm{NI}$ rates are consistently lower and have been dropping over the past 3 years. It also shows that more than twice as many referrals in England proceeded to a child protection investigation in 2013/14 compared to NI since 2011.

Data on the number of initial case conferences held or required during the year is collected across all nations although the Scottish definition is somewhat broader. Rates of case conferences held/required per 10,000 children have been increasing across England, Scotland and Wales while NI rates have remained relatively stable. Wales, in particular shows a significant increase since 2010. The figures also show that a smaller proportion of referrals result in an initial case conference in NI compared to either England or Wales.

In relation to children who become subject to a plan during the year, again rates have been steadily increasing across England, Wales and Scotland, as have the figures when calculated as a proportion of total referrals (excluding Scotland). This would indicate that such changes are not just a reflection of increasing referrals but an increasing tendency for children to be made subject to a CPP/CPR once they come into contact with the welfare systems in these countries. Conversely, the proportion of referrals proceeding to registration during the year in NI has remained consistently lower and has been reducing since 2011. 
Table 1 - Child protection investigations, initial case conferences and registrations during the years $2005-2014$ as rates per 10,000 and \% of referrals

\begin{tabular}{|c|c|c|c|c|c|c|c|c|c|c|}
\hline & 2005 & 2006 & 2007 & 2008 & 2009 & 2010 & 2011 & 2012 & 2013 & 2014 \\
\hline \multicolumn{11}{|c|}{$\begin{array}{l}\text { Rates of children per } 10,000 \text { subject to } s .47 \text { enquiries/CP investigations which started } \\
\text { during the year }\end{array}$} \\
\hline England & 62 & 65 & 66 & 69 & 75 & 79 & 98 & 109 & 110 & 123 \\
\hline $\mathrm{NI}$ & 46 & 50 & 54 & 54 & 66 & 79 & 89 & 85 & 81 & 75 \\
\hline \multicolumn{11}{|c|}{$\begin{array}{l}\text { Number of children subject to } 5.47 \text { enquiries/CP investigations which started during the } \\
\text { year as \% of total referrals }\end{array}$} \\
\hline England & 12 & 13 & 14 & 14 & 15 & 15 & 18 & 21 & 21 & 22 \\
\hline $\mathrm{NI}$ & 8 & 7 & 7 & 8 & 10 & 11 & 11 & 10 & 9 & 8 \\
\hline \multicolumn{11}{|c|}{$\begin{array}{l}\text { Rates of children subject to an initial child protection conference which started during } \\
\text { the year }\end{array}$} \\
\hline England & 34 & 34 & 35 & 36 & 39 & 39 & 47 & 49 & 52 & 56 \\
\hline Wales & - & - & 29 & 36 & 43 & 49 & 64 & 70 & 74 & 74 \\
\hline Scotland & 31 & 38 & 44 & 41 & 45 & 45 & 50 & 52 & 54 & 57 \\
\hline $\mathrm{NI}$ & 50 & 50 & 58 & 52 & 51 & 54 & 50 & 49 & 57 & 52 \\
\hline \multicolumn{11}{|c|}{$\begin{array}{l}\text { Number of children subject of an initial child protection conference as \% of total } \\
\text { referrals }\end{array}$} \\
\hline England & 7 & 7 & 7 & 8 & 8 & 7 & 9 & 9 & 10 & 10 \\
\hline Wales & - & - & 4 & 5 & 6 & 6 & 9 & 10 & 12 & 13 \\
\hline Scotland & & - & - & - & - & - & - & - & - & - \\
\hline $\mathrm{NI}$ & & - & - & - & 8 & 7 & 7 & 6 & 6 & 6 \\
\hline \multicolumn{11}{|c|}{ Rates of children per 10,000 who became the subject of a plan during the year } \\
\hline England & 28 & 28 & 30 & 30 & 34 & 39 & 43 & 46 & 46 & 52 \\
\hline Wales & 43 & 45 & 46 & 46 & 48 & 53 & 59 & 61 & 66 & 66 \\
\hline Scotland & 22 & 27 & 30 & 27 & 34 & 34 & 37 & 40 & 41 & 45 \\
\hline $\mathrm{NI}$ & 26 & 27 & 30 & 35 & 43 & 43 & 49 & 44 & 43 & 46 \\
\hline \multicolumn{11}{|c|}{ Children who became the subject of a plan during the year as \% of total referrals } \\
\hline England & 6 & 6 & 6 & 6 & 7 & 7 & 8 & 8 & 9 & 9 \\
\hline Wales & - & - & 6 & 7 & 7 & 7 & 8 & 8 & 11 & 12 \\
\hline Scotland & - & - & - & - & - & - & - & - & - & - \\
\hline $\mathrm{NI}$ & 4 & 4 & 4 & 5 & 6 & 6 & 6 & 5 & 5 & 5 \\
\hline
\end{tabular}

Ages of Children and Reason for Registration at the Census Date

All nations collect data on the reasons for a child becoming subject to a child protection plan or registration which broadly equate to the four maltreatment categories outlined in guidance. There are variations in the use multiple abuse categories and the broadening of available categories in Scotland means that data is not comparable after 2011. Nonetheless, broad trends are discernible, as are some differing patterns between nations. 
Registrations for neglect have remained consistently high across all nations while sexual abuse registrations have declined. Registrations for emotional abuse have increased substantially across England and Wales while Scottish data shows a similar pattern. Physical abuse registrations have also declined across England, Wales and Scotland, although they still accounted for almost one in five registrations in Scotland in 2010/11. NI shares a similar pattern of declining sexual abuse registration but emotional abuse has also declined and remains low while physical abuse has risen substantially, making up 42\% of registrations in 2013/14.

Fig 4

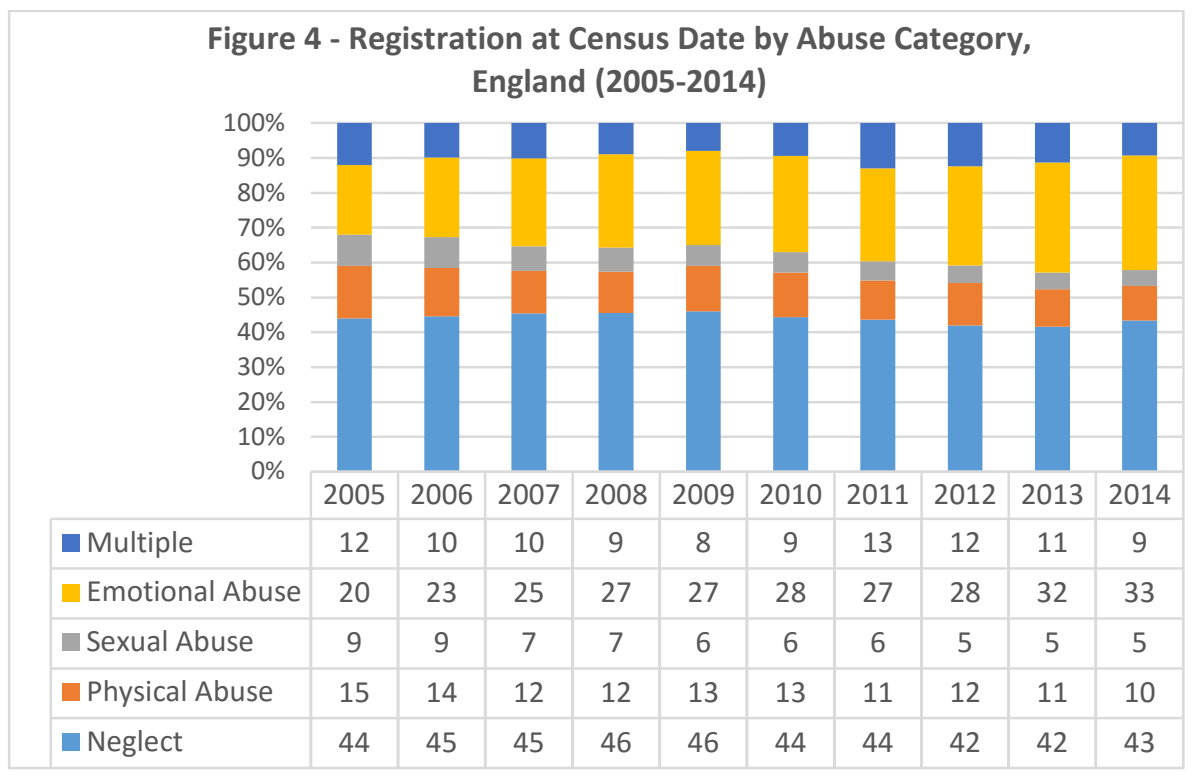

Fig 5

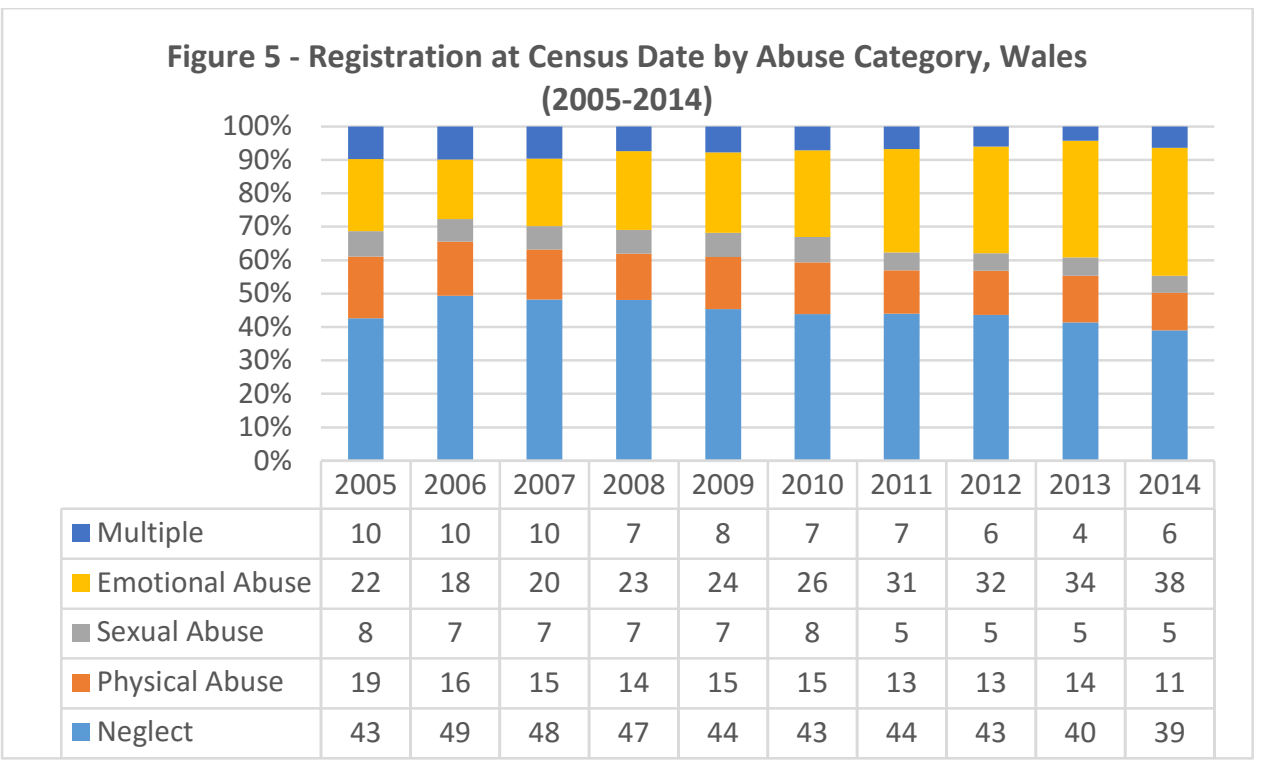

Fig 6 


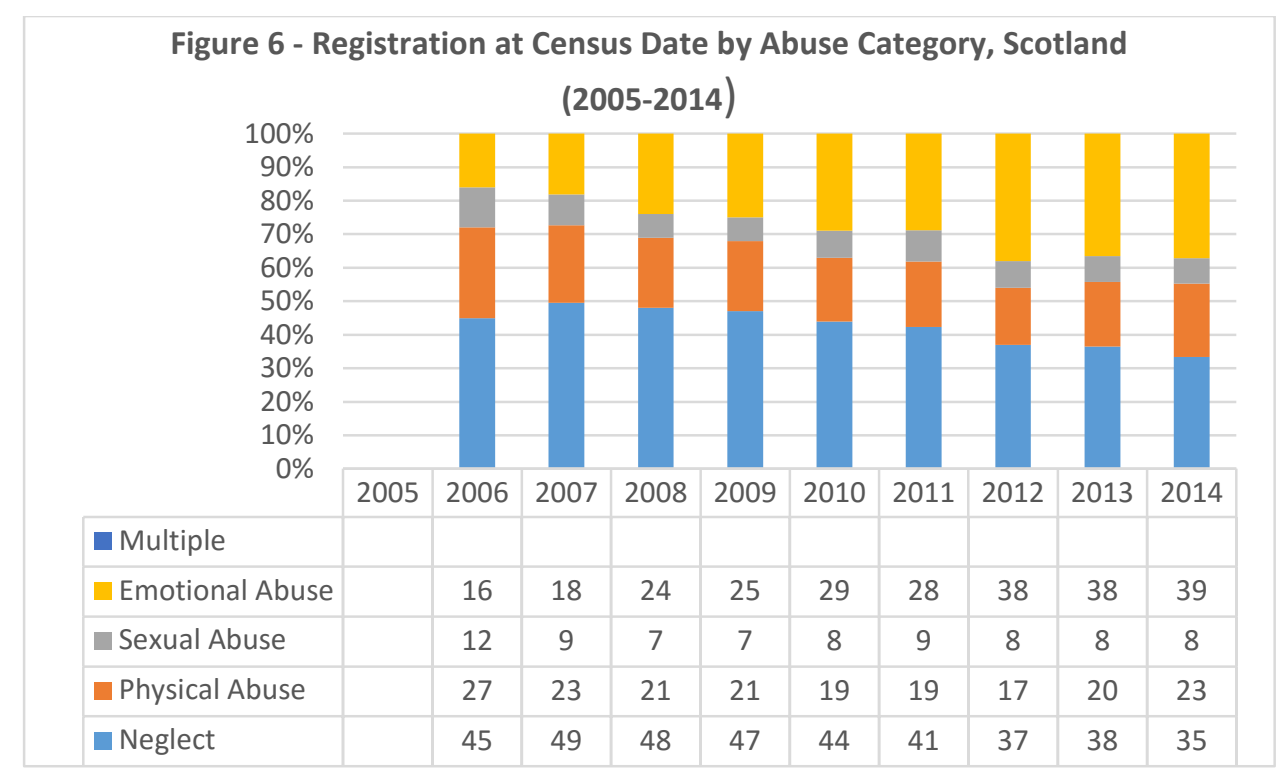

Fig 7

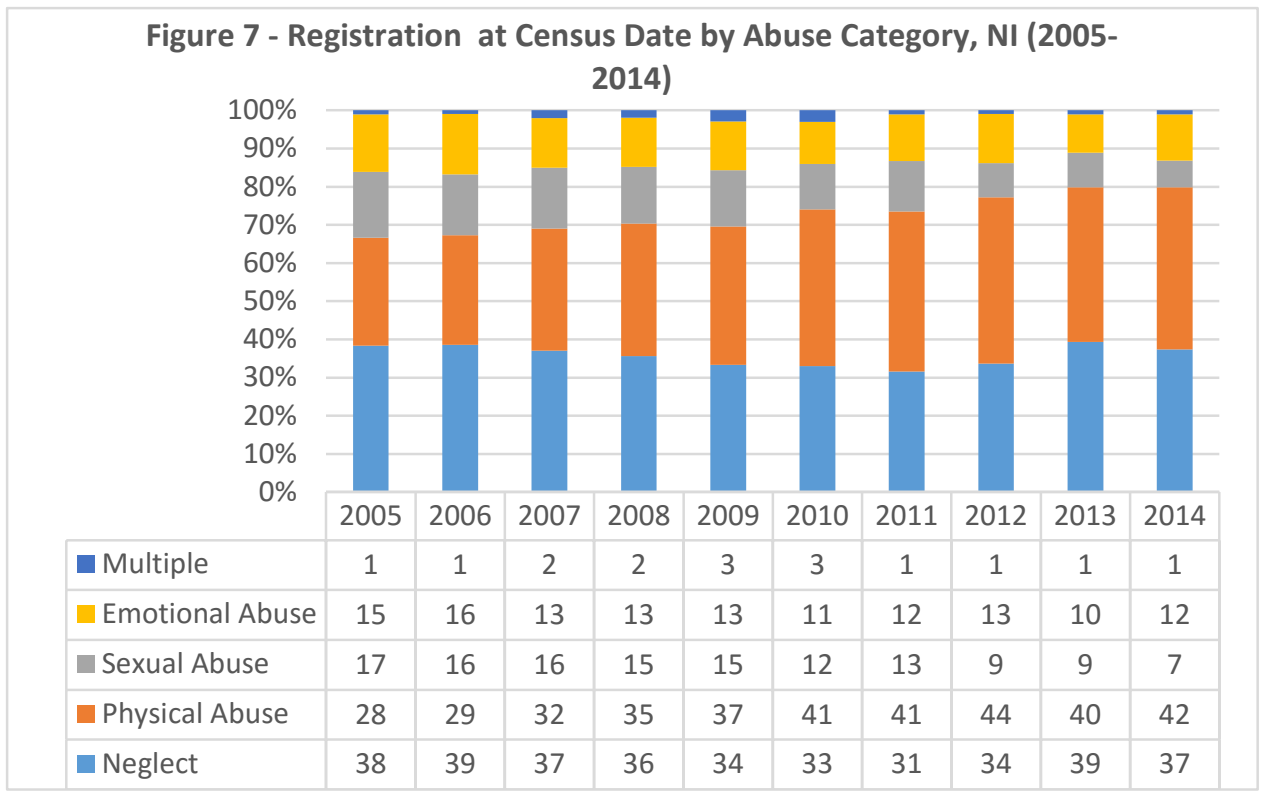

All nations publish data on the ages of children subject to CPPs/CPRs at the census date. Focusing on the 0-4 age group there is a general upward trend. Scotland has maintained the highest proportion of younger children subject to registration, England and Wales have similar but somewhat lower levels while NI, despite having historically had the lowest proportion of younger children on the register, has tended to converge with England and Wales in recent years.

\section{Fig 8}




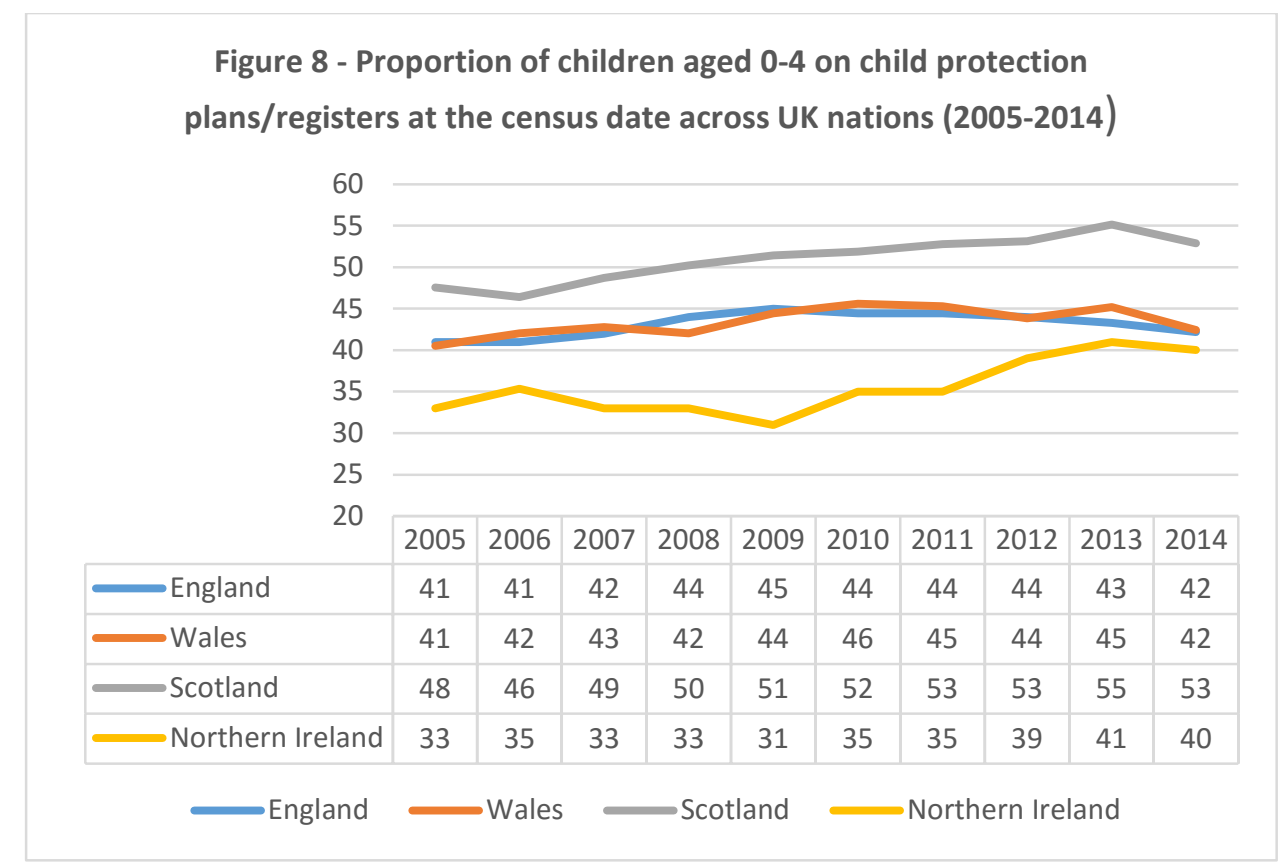

Only England and Wales publish a breakdown of category of registration by age group. As Figures 9 and 10 show the increasing registration rates for emotional abuse in both these nations has occurred primarily in the younger age group, 0-4 years, although it dropped slightly in 2013/14.

Fig 9

Figure 9 - Proportion of Registrations for Emotional Abuse by Age Group - England (2005-2014)

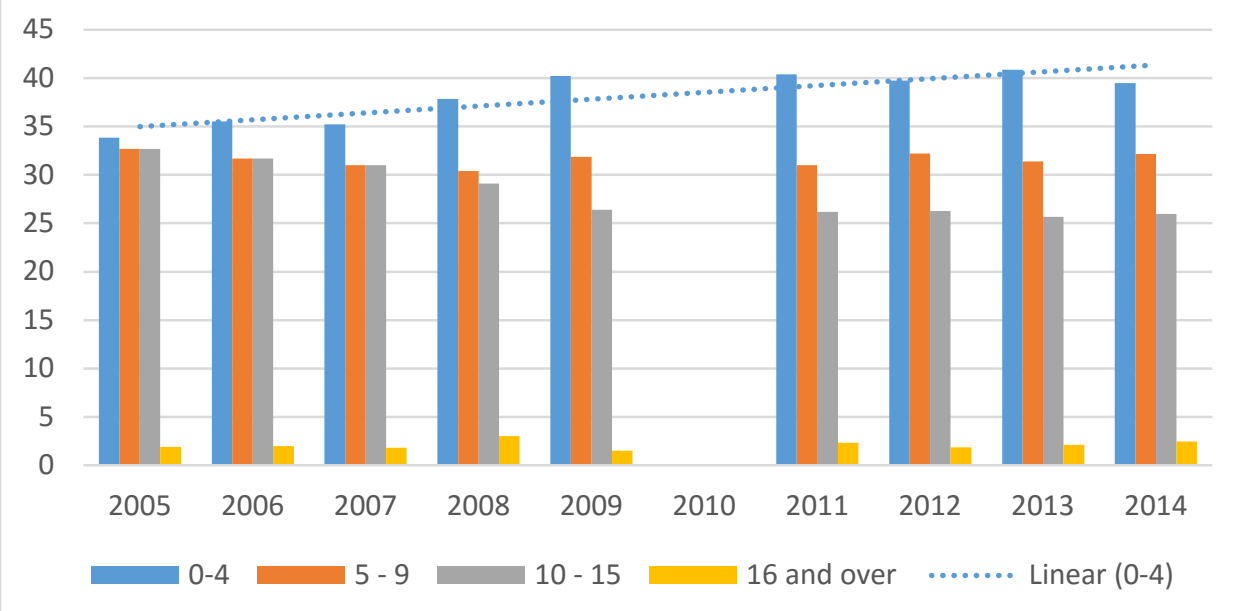

Fig 10 


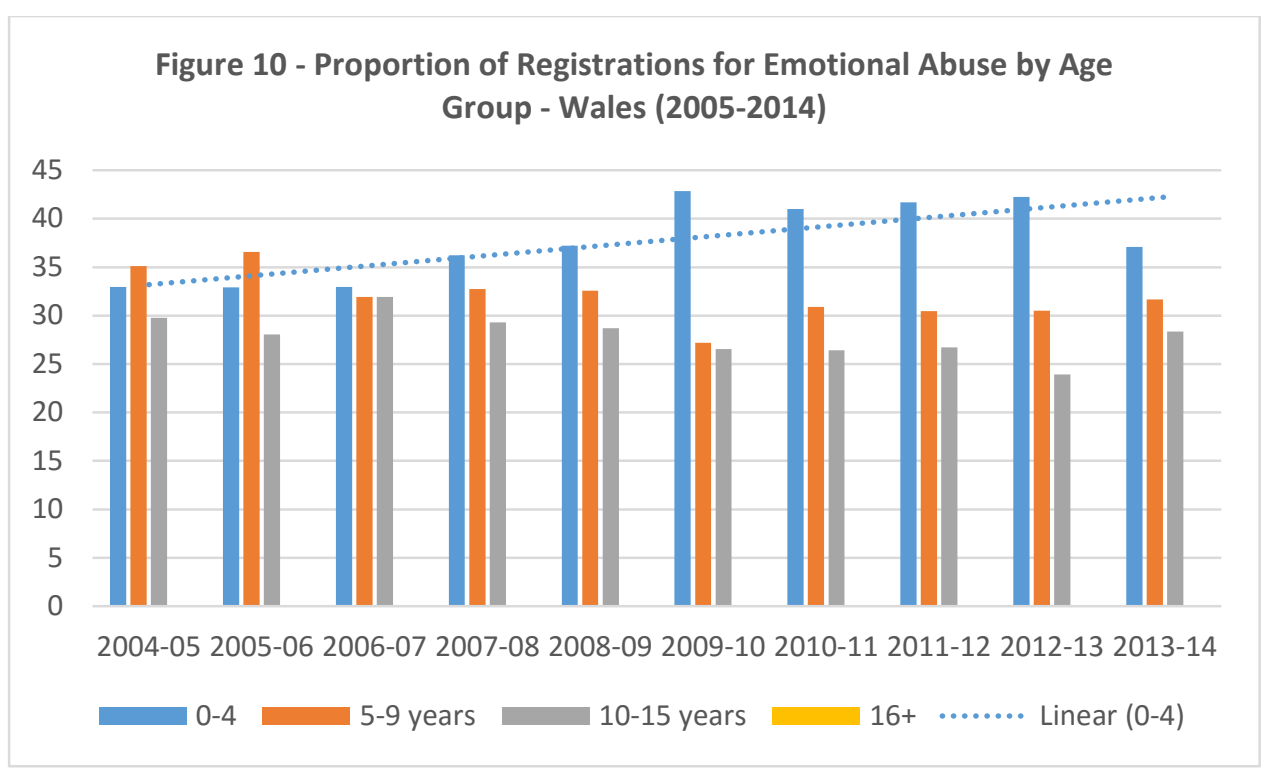

\section{DISCUSSION}

The data indicate that, over the past decade, the initial funnel for entry into the child protection system in England and NI have been widening, particularly since 2009, with $\mathrm{NI}$ having a significantly higher referral rate than any other country. This increase in referrals is often attributed to the impact of the Baby $P$ case, although the sustained nature of the rise suggests that other factors likely play a role, not least the economic downturn and large reductions in funding. Difference in referral rates in between $\mathrm{NI}$ and England may also be explained by a number of factors: better identification of need achieved through the longstanding integration of health and social care systems; the presence of a form of mandatory reporting which has been in statute for several decades; and higher levels of child poverty and deprivation. Several decades of research across many different countries evidence a strong relationship between poverty and child maltreatment (Bywaters et al., 2016) with recent longitudinal analysis (Hood et al., 2016) showing that increased deprivation drives 'demand' for English local authority services in the form of increased referrals to children's social care.

Hood et al.'s (2016) analysis also suggests that local authorities with higher demand tend to screen out more referrals and divert more cases to non-statutory services. At a national level, there is limited evidence to suggest that there are major cross national differences in cases filtered out at the referral stage as similar proportions proceed to initial assessment in England and Wales or are allocated for further action (following initial assessment of the referral) in NI. Bearing in mind that these data are not directly comparable, all three countries appear to have experienced a decrease in the proportion of cases filtered out at the referral stage. However, despite the use of similar assessment tools across the UK, how they are used to manage case allocation, potentially in conjunction with other filtering/screening methods, is not easily discernible and requires further investigation. Likewise the observation that the decrease in Welsh referrals may be partially attributable to some local authorities counting 'contacts' which required no further action as referrals points to how national figures can be effected by practice variation.

Rates of children subject to CPPs/CPR have also been increasing across England, Scotland and Wales since the early 2000s, i.e. for several years before the Baby P 
case. Historically $\mathrm{NI}$ has tended to have higher registration rates, although this has decreased in recent years and has been recently overtaken by Wales. By contrast, Scotland has consistently maintained a significantly lower level of children on the register than any other nation. However, this disparity is most probably due to the operation of the Children's Hearing System which offers an alternative route to the management of child protection cases not available in other nations. Bywaters et al., (2014) show a strong relationship between deprivation and increased risk of children becoming subject to child protection planning/registration. Qualitative research (Gillies, 2007, Canvin et al., 2007) also suggests that this more than simply a "needsled" relationship, pointing to a lack of fit between professionals construction of 'need' and the expressed need of impoverished service users which can result in the practical needs being overlooked. As such, the fact that none of the four UK nations collect basic information about deprivation or other family circumstances remains a serious omission; one made all the more significant by research which suggests that the impact of environmental factors may not always be fully appreciated or paid variable attention by social workers (Horwath, 2002; Cleaver and Walker, 2004).

When viewed within the context of Gilbert's (1997) child welfare model these high and increasing rates of registration appear indicative of system convergence around a child protection orientation. Similarly, Bilson and Martin's (2016) longitudinal analyses points to an increasing investigative orientation of the English child protection system which now encompasses greater numbers of children and families than ever before. However, data relating to cases which proceed to various stages of the child protection process during the year reveal different filtering patterns between countries. Over time England has a maintained a significantly higher investigation rate compared with $\mathrm{NI}$. In 2013/14 more than twice the proportion of referrals proceeded to investigation in England, suggesting a lower filter between these processes than in NI. The figures also show that both the rate of initial case conferences and the CPPs/CPRs have increased across England, Scotland and Wales, again with Wales showing more significant increases, particularly since 2010 . In NI the rate of initial case conferences has remained relatively stable while registration has steadily increased. However, the proportion of referrals which result in an initial case conference or registration remains consistently lower than other countries. Within the context of Gilbert's (1997) model one might see this as suggestive of a stronger family support orientation within $\mathrm{NI}$ and Scottish systems. However, as Hood et al., (2016) note, local authorities with high referrals rates exhibit a tendency to step down statutory plans quickly and be less likely to work longer term with families, a finding which might also explain NI's lower investigation and registration ratios.

Data relating to the proportion of younger children placed on child protection plans/registers show a general upward trend, particularly in Scotland and NI. Over time Scotland has maintained the highest proportion of registrations in the 0-4 age group, albeit in the context of low overall registration rates. England and Wales have similar but somewhat lower levels while NI, despite having historically had the lowest proportion of younger children on the register, has tended to converge with England and Wales in recent years. As such, in 2013/14 children aged 0-4 years made up between forty and fifty percent of child protection registrations at the census date across all UK nations. These changes no doubt reflect the strong policy focus on early intervention which is common to all UK nations and which, particularly in England, emphasises the need to intervene with urgency and a clear focus on children aged 03 years (Allen, 2011). However, the relationship between early intervention and child 
protection is by no means unproblematic. It has been argued that that the 'now or never' focus of the early intervention agenda, underpinned by the (mis)use of neuroscience, is driving coercive state intervention in the lives of an ever increasing number of families (Featherstone et al., 2014).

The data also evidence changing patterns in the abuse types used to categorise children subject to child protection planning/registration. Over the past decade the proportion of cases attributed to neglect has remained relatively stable, at around 40$45 \%$ of registrations across the UK, while sexual abuse and physical abuse have declined. Emotional abuse, on the other hand, has increased over time in England and Wales, accounting for $33 \%$ and $38 \%$ of registrations in $2013 / 14$, with Scotland exhibiting similar patterns during 2004/05-2010/11. English and Welsh data show that increases in registration for emotional abuse have primarily occurred in the 0-4 years age group, a finding which is likely reflective of an early intervention agenda which stresses the early years as a critical time period for the developing social and emotional structure of the brain, requiring sensitive and attuned parenting (Allen, 2011). Devine \& Parker's (2015) historical analysis of English data notes the significance of the shift with the 'core abuse types' of physical abuse and sexual abuse which once made up the bulk of child protection registrations now accounting for only a minority of cases.

This also mirrors changing trends internationally with the majority of children in Australia and the US now being classified under neglect or emotional abuse (Munro \& Manful, 2012). Munro \& Manful (2012) attribute this to increasing recognition of the detrimental impact of these forms of abuse although they recognise these designations have the greatest definitional ambiguity at an international level. Definitions also vary somewhat between UK nations but, more importantly, they vary over time with emotional abuse and neglect having expanded substantially (Featherstone et al., 2016). A number of national and international researchers and academics have raised highlighted the contested nature of emotional abuse and neglect, raising concerns about this apparent net-widening and, arguing for narrower abuse definitions of abuse and neglect (Lonne et al., 2009; Pelton, 2015) supported by a universal welfare model of provision and reduced focus on forensic investigation. Scott (2006) suggests this definitional broadening has not only been driven by greater recognition of the child as a psychological being but as a holder of human rights, a concept which has influenced legislative and policy development across the UK. The growth in registered child protection cases, and of emotional abuse in particular, may not just reflect the prioritisation of child protection over family support but may also reflect pragmatic decisions to categorise families' troubles in ways that bring greater access to limited resources. Thus social workers may define families' troubles in, while the ways that increase the numbers of abuse and neglect cases have increased, while the actual conditions of children's lives may not have necessarily changed.

\section{CONCLUSION}

As previous analyses have noted (Munro \& Manful, 2012), there are a number of limitations to relying on administrative datasets to compare child welfare policy and practice. Most notably, differences in what data is collected and published, coupled with variations in maltreatment definitions, thresholds for action and recording conventions, can pose particular problems. Throughout this paper we have highlighted commonalities and differences in national policy, assessment and data collection procedures in order to assess the comparability of UK child protection statistics and 
provide a tentative framework for interpreting variation. Despite a number of legislative and, operational and definitional differences, between the four UK nations, a number of national and cross-national trends are apparent. In terms of individual nations, the data show that:

- The English child protection system is characterised by a widening of the initial funnel as evidenced by increasing referral rates. It operates a comparatively low filter between referral and investigation with one in five referrals proceeding to this stage. This is accompanied by increasing numbers of families being subject to initial case conferencing and child protection planning.

- The Welsh child protection system has witnessed greater fluctuation and the initial funnel has narrowed in recent years. The proportion of cases filtered out at an early stage has reduced dramatically with the majority of cases now proceeding to assessment. This has been accompanied by a rise in the proportion of cases proceeding to initial case conference and registration.

- The NI system has the widest initial funnel with the highest level of contact between families and children's social services of any UK nation. Despite comparatively high registration rates it operates a high filter between referral and investigation with only one in ten cases proceeding to this stage. The proportion of cases which proceed to initial case conference and registration is consistently lower than in England and Wales.

- The Scottish system is characterised by very low child protection registration, primarily because of the operation of the CHS which provides an alternative legal route for processing child protection cases. The lack of referral data make it difficult to ascertain if cases are filtered in different ways from other nations.

Across UK nations there is also an on-going trend towards increased child protection planning/registration in relation to emotional abuse and in respect of children aged 0 4 years.

Although the lack of any objective bench mark for the operation of a 'good' system makes interpretation of such national differences difficult, a number of additional issues emerge from this analysis. Firstly, despite the routine annual collection of a range of statistics across all nations, such data rarely, if ever, engender any national debate as to what they say about the operation of these systems - for example, whether the direction of travel towards a more child protection orientated system involving younger children is an intentional, or even a desirable outcome? Secondly, national data returns continue to collect next to no information on the family characteristics of those who come into contact with the child protection system or the support services offered. Twenty seven years after the Children Act 1989 sought to achieve a better balance between child protection and children in need through providing a statutory basis for the provision of family support services, we still have no clear picture as to what is provided, to whom and at what stage, in any nation across the UK or what the outcomes are for children of their differential chances of being assessed as 'at risk'.

\section{References}

Allen, G (2011) Early intervention: The next steps. HM Government: London. 
All Wales Child Protection Procedures Review Group (2008). All Wales child protection procedures. Produced on behalf of All Local Safeguarding Children Boards in Wales.

Bilson, A. \& Martin, K. (2016) Referrals and Child Protection in England: One in Five Children Referred to Children's Services and One in Nineteen Investigated before the Age of Five. British Journal of Social Work, first published online: May 24, 2016.

Bunting, L. Lazenbatt, Anne. \& Wallace, I. (2010) Information sharing and reporting systems in the UK and Ireland: Professional barriers to reporting child maltreatment concerns. Child Abuse Review, Vol. 19, p. 187-202.

Bywaters, P., Brady, G., Sparks, T. and Bos, E. (2014), Child welfare inequalities: new evidence, further questions. Child \& Family Social Work. doi: 10.1111/cfs.12154

Canvin, K., Jones, C., Marttila, A., Burstrom, B. \& Whitehead, M. (2007) Can I risk using public services? Perceived consequences of seeking help and health care among households living in poverty: qualitative study. Journal of epidemiology and community health, 61(11), 984-989

Children and Young People's Strategic Partnership (2011) Children and Young People's Plan 2011 - 2014. Belfast: Children and Young People's Strategic Partnership.

Davidson, G. Bunting, L. \& Webb, MA, (2012) Families experiencing multiple adversities: a review of the international literature. Belfast: Barnardo's NI.

Department for Education and Skills (2006) Common Assessment Framework for children and young people: practitioners' guide. London: DfES

Department of Health (2000) Framework for the Assessment of Children in Need and their Families. London: The Stationary Office,

Department of Health, Social Services and Public Safety (2015). Co-operating to safeguard children - Draft Policy Guidance. Belfast: DHSSPS.

Department of Health, Social Services and Public Safety (2006b). Our children and young people: Our pledge: a ten year strategy for children and young people in Northern Ireland 2006-2016. Belfast: DHSSPS.

Department of Health, Social Services and Public Safety (2006a). Understanding the Needs of Children in Northern Ireland (UNOCINI). Belfast: DHSSPS.

Department of Health, Social Services and Public Safety (2009) Families matter: Supporting families in Northern Ireland: Regional family and parenting strategy. Department of Health, Social Services and Public Safety, Belfast.

Devine, L. and Parker, S. (2015) Rethinking Child Protection Strategy: Learning from Trends, Bristol, Centre for Legal Research, University of the West of England.

Family and Parenting Institute (2012), The Impact of Austerity Measures on Households with Children. London: Family and Parenting Institute.

Featherstone, B., Morris, K. and White, S. (2014) A Marriage Made in Hell: Early Intervention Meets Child Protection. British Journal of Social Work, 44: 1735-1749. 
Featherstone, B., Gupta, A., Morris, K. \& Warner, J. (2016) Let's stop feeding the risk monster: Towards a social model of 'child protection'. Families, Relationships and Societies, available online: February 15, 2016.

Frost, N., Abbott, S. \& Race, T. (2015) Family Support: Prevention, Early Intervention and Early Help. Cambridge: Polity Press.

Gilbert, N., Parton, N., \& Skivenes, M. (2011). Child protection systems. International trends and orientations. New York: Oxford University Press.

Gilbert, N. (1997) Combatting Child Abuse: International perspectives and trends. New York: Oxford University Press.

Gillies, V. (2007) Marginalised Mothers: ExploringWorking Class Experiences of Parenting. Routledge, Abingdon.Lonne, R.,Parton,N., Thomson,J. \& Harries,M.(2009).Reforming child protection. London: Routledge.

Hastings, A., Bailey, N., Bramley, G., Gannon, M. \& Watkins, D. (2015) The cost of the cuts: The impact on Local government and poorer Communities. Yorjk: Joseph Rowntree Foundation

Hood, R., Goldacre, A., Grant, R. \& Jones, R. (2016) Exploring Demand and Provision in English Child Protection Services. British Journal of Social Work. First published online: May 13, 2016.

HM Government (2004) Every Child Matters. London: Department for Education and Skills.

HM Government (2012) Social Justice: Transforming Lives. HM Government, London.

HMSO (1991) Working Together Under the Children Act. London: HMSO

HM Treasury (2010) Spending Review 2010. London: The Stationary Office

Jütte, S., Bentley, H., Miller, P. \& Jetha, N. (2015) How Safe Are Our Children.

London: National Society for the Prevention of Cruelty to Children.

McCormick, J. (2013) A review of Devolved Approaches to Child Poverty. York: Joseph Rowntree Foundation.

McGhee, J. \& Waterhouse, L., (2012), 'Massachusetts and Scotland: From Juvenile Justice to Child Welfare? Child Welfare: journal of the Child Welfare League of America, 91(5):169-191

Munro, E. \& Manful, E. (2012) Safeguarding children: a comparison of England's data with that of Australia, Norway and the United States. London: Department for Education.

Munro, E. (2011) The Munro Review of Child Protection: Final Report: A ChildCentred Approach (Vol. 8062), London, The Stationery Office.

NI Executive (2011) Improving children's life chances - The child poverty strategy. Belfast: NI Executive.

Office of National Statistics (2014) Population Estimates for UK, England and Wales, Scotland and Northern Ireland, London: ONS, available at 
https://www.ons.gov.uk/peoplepopulationandcommunity/populationandmigration/pop ulationestimates/datasets/populationestimatesforukenglandandwalesscotlandandnort hernireland

Parton, N., Parton, N. \& Berridge, D. (2011) Child protection in England, in Child Protection Systems: International Trends and Orientations. G., Parton, N. \& N. Skiveness, M. (eds.). New York: Oxford University Press, p. 60 - 85.

Pelton, L. (2015) The continuing role of material factors in child maltreatment and placement Child Abuse \& Neglect, 41, 30-39.

Scottish Government (2014b). National Guidance for Child Protection in Scotland 2014. Edinburgh: Scottish Government.

Scottish Government (2012) National Parenting Strategy. Edinburgh: Scottish Government.

Scottish Government (2008) A Guide to Getting it right for every child, Edinburgh, Scottish Government

Scottish Government (2014) The Early Years Framework. Edinburgh, Scottish Government

Scottish Government (2011) Child Poverty Strategy for Scotland - Our Approach 2014 - 2017. Edinburgh, Scottish Government

Social Exclusion Task Force (2008) Think family: improving the life chances of families at risk. Cabinet Office Social Exclusion Task Force, London.

Stafford A., Parton N., Vincent S., Smith C. (2012) Child Protection Systems in the United Kingdom: A Comparative Analysis. London: Jessica Kingsley Publishers.

Stafford A., Vincent S., Parton N. (2010) Child Protection Reform across the UK. London: Jessica Kingsley; 2010

Tilbury, C., \& Thoburn, J. (2008). Children in out-of-home care in Australia International comparisons. Children Australia, 33(3), 5-12

Welsh Assembly Government (2011) Child poverty strategy for Wales. Cardiff: Welsh Government

Welsh Government (2004). Safeguarding children: working together under the Children Act 2004. Cardiff: Welsh Government

Welsh Government (2011). Children and young people: rights to action. Cardiff: Welsh Government 


\section{Supplementary Material - Definitions and comparability of official child protection statistics and related data sources}

\begin{tabular}{|c|c|c|c|}
\hline Measure & Country & Data definition & Comparability \\
\hline \multicolumn{4}{|c|}{ Data collected at the Census Date } \\
\hline \multirow[t]{4}{*}{ The census date } & England & $31^{\text {st }}$ March & \multirow{4}{*}{$\begin{array}{l}\text { Different date in S than in } \\
\mathrm{E}, \mathrm{W} \text { and NI but all } \\
\text { covering a } 12 \text { month time } \\
\text { period - comparable. }\end{array}$} \\
\hline & Wales & $31^{\text {st }}$ March & \\
\hline & Scotland & $31^{\text {st }}$ July & \\
\hline & $\mathrm{NI}$ & $31^{\text {st }}$ March & \\
\hline \multirow{4}{*}{$\begin{array}{l}\text { Children subject } \\
\text { to child } \\
\text { protection } \\
\text { plans/ } \\
\text { registration } \\
\text { subject at } \\
\text { census date }\end{array}$} & England & Children subject to case planning and placed on a child protection plan & \multirow{4}{*}{$\begin{array}{l}\text { Different terminology but } \\
\text { ostensibly the same thing - } \\
\text { comparable }\end{array}$} \\
\hline & Wales & $\begin{array}{l}\text { Children subject to case planning and placed on a child protection } \\
\text { register }\end{array}$ & \\
\hline & Scotland & $\begin{array}{l}\text { Children subject to case planning and placed on a child protection } \\
\text { register }\end{array}$ & \\
\hline & $\mathrm{NI}$ & $\begin{array}{l}\text { Children subject to case planning and placed on a child protection } \\
\text { register }\end{array}$ & \\
\hline \multirow[t]{3}{*}{$\begin{array}{l}\text { Reason for } \\
\text { registration or } \\
\text { being subject to } \\
\text { CP plan at } \\
\text { census date }\end{array}$} & England & $\begin{array}{l}\text { Recorded for the category of abuse as assessed when the child } \\
\text { protection plan commenced (initial) and the most recent category of } \\
\text { abuse assigned to the child protection plan (latest). Categories - Neglect, } \\
\text { physical abuse, sexual abuse, emotional abuse, multiple (not } \\
\text { recommended) }\end{array}$ & \multirow{3}{*}{$\begin{array}{l}\text { Main differences relate to } \\
\text { multiple abuse } \\
\text { designations. NI data } \\
\text { allows for combination of } \\
\text { single abuse categories } \\
\text { with multiple abuse } \\
\text { categories where there is a } \\
\text { primary abuse type - this } \\
\text { allows for comparability. } \\
\text { Data in W cannot be } \\
\text { disaggregated this way but } \\
\text { figures indicate less than } \\
\text { 10\% involve multiple } \\
\text { categorisations so data is } \\
\text { broadly comparable. Due }\end{array}$} \\
\hline & Wales & $\begin{array}{l}\text { Recorded for the category of abuse as assessed when the child } \\
\text { protection plan commenced. Categories - Neglect, physical abuse, sexual } \\
\text { abuse, emotional abuse only; series of multiple abuse categories which } \\
\text { are not disaggregated by primary abuse type }\end{array}$ & \\
\hline & Scotland & $\begin{array}{l}\text { Prior to } 2011 \text { S used similar categories - physical injury, sexual abuse, } \\
\text { emotional abuse and physical neglect. In adopted a much broader } \\
\text { categorisation framework which included the previous categories as well } \\
\text { as a range of other reason including domestic violence, addiction etc. } \\
\text { Individual cases can have multiple categorisations and cannot be } \\
\text { disaggregated. }\end{array}$ & \\
\hline
\end{tabular}




\begin{tabular}{|c|c|c|c|}
\hline & $\mathrm{NI}$ & $\begin{array}{l}\text { Reason for registration - physical, sexual, emotional and neglect; sexual } \\
\text { abuse/physical abuse by primary abuse type, neglect and physical abuse } \\
\text { by primary abuse type and neglect and sexual abuse by primary abuse } \\
\text { type; sexual, physical and neglect }\end{array}$ & $\begin{array}{l}\text { to changes to in recording } \\
\text { practice Scottish data is } \\
\text { not comparable after } 2011 \\
\text { but data before this is } \\
\text { broadly comparable to E, } \\
\text { W \& NI. }\end{array}$ \\
\hline \multirow{4}{*}{$\begin{array}{l}\text { Age of children } \\
\text { subject to a CPP } \\
\text { or registration } \\
\text { at census date }\end{array}$} & England & $\begin{array}{l}\text { No of children banded in age categories: under } 1 ; 1-4 \text { years; } 5-9 \text { years; } \\
10-15 \text { years; } 16 \text { \& over }\end{array}$ & \multirow{4}{*}{$\begin{array}{l}\text { Slightly different } \\
\text { categorisations across } \\
\text { nations - but can be } \\
\text { recoded into groups } 0-4,5- \\
15 \text { and } 16+\text { to ensure } \\
\text { comparability }\end{array}$} \\
\hline & Wales & $\begin{array}{l}\text { No of children banded in age categories: under } 1 ; 1-4 \text { years; } 5-9 \text { years; } \\
10-15 \text { years; } 16-17 \text { years; } 18-20 \text { years; } 21 \text { years + }\end{array}$ & \\
\hline & Scotland & $\begin{array}{l}\text { No of children banded in age categories: under } 1 ; 1-4 \text { years; } 5-11 \text { years; } \\
12-15 \text { years; } 16-17 \text { years; } 18-21 \text { years }\end{array}$ & \\
\hline & $\mathrm{NI}$ & $\begin{array}{l}\text { No of children banded in age categories: under } 1 ; 1-4 \text { years; } 5-11 \text { years; } \\
12-15 \text { years; } 16+\text { years }\end{array}$ & \\
\hline \multicolumn{4}{|c|}{ Data Collected During the Year } \\
\hline & England & $\begin{array}{l}\text { A referral is defined as a request for services to be provided by children's } \\
\text { social care and is in respect of a child who is not currently in need. If a } \\
\text { child has more than one referral in the year then each instance is } \\
\text { counted. }\end{array}$ & \multirow[t]{4}{*}{$\begin{array}{l}\text { Same definitions in } \mathrm{E}, \mathrm{W} \\
\text { and } \mathrm{NI} \text { - comparable. } \\
\text { No data for } \mathrm{S}\end{array}$} \\
\hline & Wales & $\begin{array}{l}\text { A referral is defined as a request for services to be provided by children's } \\
\text { social care and is in respect of a child who is not currently in need. If a } \\
\text { child has more than one referral in the year then each instance is } \\
\text { counted. }\end{array}$ & \\
\hline & Scotland & Not available & \\
\hline & $\mathrm{NI}$ & $\begin{array}{l}\text { A referral is defined as a request for services to be provided by a social } \\
\text { services department where the case is not already open. This is } \\
\text { presented in national statistics as a child in need referral: a referral of a } \\
\text { child to Social Services, regardless of the source of referral. A child may } \\
\text { be referred several times over the course of a year. }\end{array}$ & \\
\hline
\end{tabular}




\begin{tabular}{|c|c|c|c|}
\hline \multirow{4}{*}{$\begin{array}{l}\text { Assessments } \\
\text { completed/ } \\
\text { children } \\
\text { referred } \\
\text { allocated for } \\
\text { further action } \\
\text { during the year }\end{array}$} & England & $\begin{array}{l}\text { No of initial assessment completed - if a child was the subject of more } \\
\text { than one assessment during the reporting year, each assessment is } \\
\text { counted separately. }\end{array}$ & \multirow{2}{*}{$\begin{array}{l}\text { E and W collect data on } \\
\text { initial assessments } \\
\text { completed during the year } \\
\text { and include multiple } \\
\text { counts per child. }\end{array}$} \\
\hline & Wales & $\begin{array}{l}\text { No of initial assessment completed - if a child was the subject of more } \\
\text { than one assessment during the reporting year, each assessment is } \\
\text { counted separately. }\end{array}$ & \\
\hline & Scotland & Not available & \multirow[b]{2}{*}{$\begin{array}{l}\text { There are no NI data on } \\
\text { the no. of assessments } \\
\text { completed but there are } \\
\text { data on cases allocated for } \\
\text { further action through } \\
\text { either service provision or } \\
\text { assessment. Not directly } \\
\text { comparable although } \\
\text { English and Welsh } \\
\text { guidance allows for similar } \\
\text { categorisation of actions } \\
\text { resulting from a referral, } \\
\text { i.e. an initial or continuous } \\
\text { assessment; the provision } \\
\text { of information or advice; } \\
\text { referral to another } \\
\text { agency; or no further } \\
\text { action. }\end{array}$} \\
\hline & $\mathrm{NI}$ & $\begin{array}{l}\text { Children Referred by Current Status at census date: } \\
\text { - Inappropriate Referral: An inappropriate childcare referral to Social } \\
\text { Services, referred back to referral source. } \\
\text { No further action required: Not required to allocate for full assessment } \\
\text { of need due to the query being dealt with at referral stage, e.g. advice on } \\
\text { social security, health and social services etc. } \\
\text { No further action taken: Unable to meet needs of the client referred, } \\
\text { perhaps due to lack of skilled resources to deal with the case. Unmet } \\
\text { need may be recorded. } \\
\text { Allocation for service/assessment: Upon initial assessment of referral, it } \\
\text { is allocated to social services professional/team to carry out full } \\
\text { assessment of need for client or for provision of a service. } \\
\text { Other: These are cases which are not allocated to one of the above } \\
\text { categories, including cases awaiting a decision (pending cases). }\end{array}$ & \\
\hline \multirow{3}{*}{$\begin{array}{l}\text { Child protection } \\
\text { investigations/ } \\
\text { enquiries } \\
\text { started during } \\
\text { the year }\end{array}$} & England & $\begin{array}{l}\text { All children who were subject to section } 47 \text { enquiries which started in } \\
\text { the year - more than one occasion per child recorded separately. }\end{array}$ & \multirow{3}{*}{$\begin{array}{l}\text { Only available in } \mathrm{E} \text { and } \mathrm{NI} \\
\text { and refers to similar legal } \\
\text { requirements to } \\
\text { investigate child protection } \\
\text { concerns although }\end{array}$} \\
\hline & Wales & Not available & \\
\hline & Scotland & Not available & \\
\hline
\end{tabular}




\begin{tabular}{|c|c|c|c|}
\hline & $\mathrm{NI}$ & $\begin{array}{l}\text { Child protection investigations during the year - conducted under Article } \\
66 \text { of the Children Order } 1995 \text { - relates to the year ending at the census } \\
\text { date and therefore, referrals received at the end of this period may not } \\
\text { yet have resulted in an investigation }\end{array}$ & $\begin{array}{l}\text { terminology varies - } \\
\text { broadly comparable }\end{array}$ \\
\hline \multirow{4}{*}{$\begin{array}{l}\text { Initial case } \\
\text { conferences } \\
\text { held/required } \\
\text { during the year } \\
\text { during the year }\end{array}$} & England & $\begin{array}{l}\text { Number of children who were the subject of an initial child protection } \\
\text { conference which started during the year }\end{array}$ & \multirow{4}{*}{$\begin{array}{l}\text { All nation collect data on } \\
\text { initial case conferences } \\
\text { during the year although } \\
\text { terminology differs in } \\
\text { terms of whether are not } \\
\text { they were held, required } \\
\text { or completed. S uses a } \\
\text { somewhat broader } \\
\text { category which includes } \\
\text { pre-birth and transfer case } \\
\text { conferences - broadly } \\
\text { comparable. }\end{array}$} \\
\hline & Wales & $\begin{array}{l}\text { The number of initial child protection conferences that were due in the } \\
\text { year }\end{array}$ & \\
\hline & Scotland & $\begin{array}{l}\text { Number of initial, pre-birth and transfer child protection case } \\
\text { conferences }\end{array}$ & \\
\hline & $\mathrm{NI}$ & Number of initial case conferences completed during the year & \\
\hline \multirow{4}{*}{$\begin{array}{l}\text { Children subject } \\
\text { to a CPP or } \\
\text { registration } \\
\text { during the year }\end{array}$} & England & As per definition at the census data & \multirow[t]{4}{*}{ See above } \\
\hline & Wales & As per definition at the census data & \\
\hline & Scotland & As per definition at the census data & \\
\hline & $\mathrm{NI}$ & As per definition at the census data & \\
\hline
\end{tabular}

\section{Source Material}

\section{England}

Department for Education (DfE) (2015a) Children in Need Census 2014 to 2015: Guide for Local Authorities, available online at https://www.gov.uk/government/uploads/system/uploads/attachment data/file/299928/DFE-00338-2014.pdf 


\section{RUNNING HEAD - TRENDS IN CHILD PROTECTION}

Department for Education (2014) Characteristics of children in need in England, 2013-14. London: Department for Education, available online at https://www.gov.uk/government/uploads/system/uploads/attachment_data/file/367877/SFR43_2014_Main_Text.pdf.

Department for Education (2014) Characteristics of children in need in England, 2013-14 - National and Local Authority Tables. London: Department for Education, available online at

https://www.gov.uk/government/uploads/system/uploads/attachment data/file/367878/SFR43 2014 Tables.xlsx

\section{Wales}

Statistics for Wales (2014) Referrals, assessments and social services for children, Wales, 2013-14. Cardiff: Statistics for Wales, available at http://gov.wales/docs/statistics/2014/140903-referrals-assessments-social-services-children-2013-14-en.pdf

Welsh Government (2015) Guidance Notes for the completion of CHILDREN IN NEED CENSUS 2016, Cardiff: Welsh Government, available at http://gov.wales/docs/statistics/2016/160331-wales-children-need-census-2016-guidance-en.pdf.

StatsWales website (statswales.gov.wales)

- Service provision, available at https://statswales.gov.wales/Catalogue/Health-and-Social-Care/Social-Services/ChildrensServices/Service-Provision

- Children in Need, available at, https://statswales.gov.wales/Catalogue/Health-and-Social-Care/Social-Services/ChildrensServices/Children-in-Need

\section{Scotland}

Scottish Government (2015) Child Protection Data Specification - Guidance notes, Edinburgh: Scottish Government, available at http://www.gov.scot/Topics/Statistics/ScotXed/ChildrenandYoungPeople/ChildProtection/SurveyDocuments

Scottish Government (2014) Children's Social Work Statistics Scotland, 2013-14, Edinburgh: Scottish Government, available at http://www.gov.scot/Resource/0047/00474429.pdf 


\section{RUNNING HEAD - TRENDS IN CHILD PROTECTION}

Scottish Government (2014) Children's Social Work Statistics Scotland, 2013-14 - Tables and Charts, Edinburgh: Scottish Government, available at http://www.gov.scot/Publications/2015/03/4375/downloads\#res474429

Scottish Government (2014) Children's Social Work Statistics Scotland, 2013-14 - Additional Tables, Edinburgh: Scottish Government, available at http://www.gov.scot/Topics/Statistics/Browse/Children/PubChildrenSocialWork/AdditionalTables2014-15

\section{Northern Ireland}

Department of Health, Social Services and Public Safety (2014) Children's Social Care Statistics, 2013/2014. Department of Health, Social Services and Public Safety: Belfast, available at https://www.health-ni.gov.uk/sites/default/files/publications/dhssps/child-social-care-1314.pdf

Department of Health, Social Services and Public Safety (2014) Children's Social Care Statistics, 2013/2014 - Statistics Tables. Department of Health, Social Services and Public Safety: Belfast, available at https://www.health-ni.gov.uk/publications/childrens-social-care-statisticsnorthern-ireland-201112-201314 
RUNNING HEAD - TRENDS IN CHILD PROTECTION 